\title{
294. Die Sartoriusplastik zur Sanierung der infizierten Hüftgelenkshöhle
}

\author{
P. Habermeyer, L. Schweiberer, D. Wilker und A. Betz \\ Chirurgische Klinik und Poliklinik Innenstadt der Universität München, \\ Nußbaumstraße 20, D-8000 München 2
}

\section{Transposition of the Sartorius Muscle for Treatment of an Infected Hip Joint}

Summary. For treatment of infected hip joints we use the proximally based sartorius muscle. After ligation of the vessels in the distal part $(30 \mathrm{~cm})$ of the muscle, the sartorius muscle is elevated and transposed to the floor of the deep-joint cavity. By completely filling the space defect, reinfection of the osteomyelitis cavity is prevented. In addition, the transposed muscle flap directs optimal blood perfusion to the hypoxemic capsule tissue via its own vascular pedicle.

Key words: Infection of hip joint - Sartorius muscle.

Zusammenfassung. Die tiefe Infektion des Hüftgelenkes führt zur irreversiblen pyogenen Knochen-Knorpelzerstörung oder zur septischen Prothesenlockerung bei TEP. Zur Sanierung der infizierten Hüftgelenkshöhle verwenden wir den proximal gestielten M. sartorius, er wird bis auf $30 \mathrm{~cm}$ distal gehoben und bündig bis auf den Boden der tiefen Gelenkshöhle eingeschwenkt. Durch die lückenlose Defektauffüllung wird der Reinfekt der osteomylitischen Gelenkshöhle vermieden. Der transponierte Muskellappen bringt über den eigenen Gefäßstiel eine optimale Durchblutung in die hypoxämische Grenzzone.

Schlïsselwörter: Hüftgelenksinfektion - M. sartorius.

\section{Erfahrung mit einer Kombination von Mezlocillin/Sisomicin in der Unfallchirurgie}

\author{
E. Lais und P. Hertel \\ Rudolf-Virchow-Krankenhaus, Augustenburger Platz 1, 1000 Berlin 65
}

\section{Experiences with the Combination of Mezlocillin and Sisomicin in Trauma Surgery}

\begin{abstract}
Summary. The clinical and bacteriological efficacy of the combination of mezlocillin and sisomicin was studied in 34 patients from the Department of Accident Surgery. In 11 cases the combination was used for treatment of manifest infections, and 23 patients received perioperative prophylaxis. Among them were patients with open fractures, patients with sizeable soft-tissue damage, and patients with pathological fractures. In 34 cases the combination of antibiotics was successful and the germ content was isolated. In 6 patients we investigated the concentration of Mezlocillin in serum, wound liquid, and bone. The results are discussed.
\end{abstract}

Key words: Trauma - Antibiotics - Tissue concentration.

Zusammenfassung. Eine Kombination von Mezlocillin/Sisomicin wurde bei unterschiedlichen Indikationen zur Prophylaxe und Therapie von Infektionen bei 34 stationären Patienten der Abteilung für Unfallchirurgie eingesetzt. Der klinische sowie bakteriologische Erfolg wurde anhand von Verlaufsbeobachtungen sowie bakteriologischer Aufarbeitung der Wundflüssigkeit bzw. Redondrainagespitzen kontrolliert. Außerdem wurden bei 6 Patienten Konzentrationsbestimmungen des Mezlocillin im Serum, dem Wundsekret und im Knochen vorgenommen und mit den bereits vorliegenden Untersuchungen verglichen. Die Therapie bzw. Prophylaxe waren in 34 Fällen erfolgreich, das gefundene Keimspektrum wurde mit der angegebenen Kombination erfaßt. Die Verträglichkeit war in allen Fällen gut.

Schliisselwörter: Trauma - Antibiotica - Gewebekonzentration. 